\title{
DOES EDUCATION MATTER? MYTHS ABOUT EDUCATION AND ECONOMIC GROWTH
}

\section{Por Tatiana Tinoco}

Mestranda em Administração de Empresas pela FGV-EAESP

E-mail: tatianat@fgvsp.br

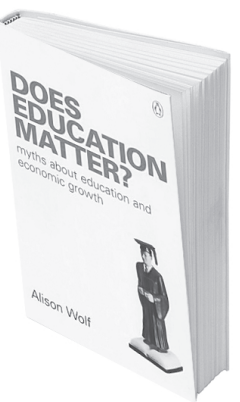

DOES EDUCATION MATTER? MYTHS ABOUT EDUCATION AND ECONOMIC GROWTH

De Alison Wolf

London : Penguin Books, 2002. 352p.
Educação foi sempre um tema freqüente tanto em pesquisas acadêmicas, quanto na mídia ou - principalmente - nos discursos políticos. Os anos 1990 e a emergência da "Sociedade do Conhecimento" aumentaram ainda mais a preocupação e o debate acerca do tema. Os governos passam a investir cada vez mais em educação e esse se torna o grande lema das campanhas políticas a partir de então. O foco sai, dessa forma, do processo produtivo e passa às pessoas, reconhecendo assim seu papel estratégico em um novo contexto, no qual o que realmente importa é o conhecimento.
O princípio básico que está por detrás dessa retórica é a crença de que educação traz progresso econômico; pensamento este que tem sua origem na teoria econômica a qual destaca o papel da educação como um fator crítico, para o desenvolvimento econômico e para o aumento do bem-estar social. Em particular, essa teoria considera a educação como o primeiro elo da cadeia por meio da qual o conhecimento é disseminado na economia, contribuindo para a acumulação de capital humano: quanto mais alto o capital humano maior será a produtividade e conseqüentemente maior a possibilidade de inovação.
Em seu mais recente livro - elogiado pela crítica - Does Education Matter? Myths about education and economic growth, Alison Wolf afirma que essa falácia econômica está comprometendo a qualidade da educação no Reino Unido. A autora questiona tanto os discursos quanto a quantidade de investimentos feita pelos governos nos últimos tempos na tentativa de que esses retornem em forma de crescimento econômico para a região. Não se trata de uma crítica infundada de quem não tem familiaridade com o assunto, mas sim do pensamento de uma acadêmica e pesquisadora do 
London's Institute of Education que, durante muitos anos, trabalhou para o congresso norte-americano, em uma agência federal, analisando as políticas educacionais adotadas. E é exatamente sua formação que torna sua abordagem tão inesperada e controversa.

É importante ressaltar que Wolf em nenhum momento questiona a validade da educação individual: ao contrário, mostra, desde o segundo capítulo, dados que comprovam que, em geral, aqueles com maior nível de educação recebem salários maiores do que pessoas de mesmo grupo e idade mas com menor nível de instrução. Assim, no nível individual, afirma a autora, não há dúvidas de que "ter as qualificações corretas, nos ramos corretos, das instituições corretas" (p. 244) é cada vez mais necessário. Necessidade esta que vem do fato de educação ser um "bem posicional". Isto é, os altos salários não vêm do fato de que se é "bem" educado, mas do fato de que se é mais educado do que aquele que está ao seu lado; não se trata de ter ou não determinados conhecimentos, mas de ter supostamente mais conhecimentos do que as outras pessoas.

Wolf ainda lembra a importância de se fazer uma distinção clara entre países desenvolvidos e países em desenvolvimento, uma vez que, no primeiro caso, a educação é compulsória até determinada idade - entre 15 e 18 anos -, o que garante aos estudantes pelo menos concluírem o chamado nível médio de educação, enquanto no segundo ainda é possível, e comum, encontrarem-se níveis elevados de analfabetismo e ou abandono escolar. Aqui ela reforça a idéia de que não se trata de questionar a educação básica fornecida às crianças, esta sim deve ser garantida pelo governo, pois é a única que comprovadamente gera ganhos econômicos tanto às pessoas quanto ao país, mas de questionar os gastos exorbitantes em educação superior, e é exatamente esse ponto que é tratado a partir do capítulo três.

A expansão da educação, afirma a autora, deixou de ter um motivo externo e passou a ser um fim em si mesmo; treinamentos, qualificações e vagas nas universidades são tratados como inquestionavelmente desejáveis. Porém, os governos que investem nessa multibilionária indústria da educação desejam apenas o crescimento econômico, um crescimento que, segundo ela, não vem.

E não vem em função da massificação da educação decorrente das políticas públicas que privilegiam como o mais importante fator aspectos econômicos e deixam de lado a função social da educação que é expansão do conhecimento individual, "do crescimento moral, intelectual, estético e espiritual" (p.254).

Quando, portanto, acredita-se que mais educação gerará mais crescimento e massifica-se o acesso às universidades, torna-se necessário estabelecer metas de ordem quantitativa para guiar e monitorar esse processo. Assim, passa-se a valorizar o que pode ser facilmente contado e mensurado - o que, por definição, já exclui qualquer análise qualitativa do que se está produzindo. Ainda, como qualquer processo em que se esperam ganhos de escala, as pressões sobre os custos emergem. Parece contraditório pensar que é necessário atender cada vez mais a um número maior de pessoas, o que portanto demandará uma infra-estrutura cada vez maior, com a mesma soma de investimentos, e isso só é possível em detrimento da qualidade. Assim, professores leci- onam em classes cada vez mais lotadas e têm cada vez menos tempo para se dedicar aos alunos. Somas de investimento são alocadas de forma igualitária entre as universidades, pois dificilmente se justificaria para a sociedade investimentos desiguais uma vez que a função desse tipo de política é justamente dar oportunidades iguais. Com isso, os melhores programas de pesquisa acabam sendo prejudicados, pois recebem investimentos menores do que o necessário para a realização de suas pesquisas.

É essa valorização do aspecto quantitativo, sem contrapartida econômica evidente, que Alison Wolf critica. Seria realmente necessário que $50 \%$ da população tivesse educação superior, como quer o governo inglês? Ou seria essa uma busca apenas em nome da expansão pela expansão? A autora espera que questões como essa tragam à discussão que tipo de educação realmente é desejada para as gerações futuras..

É inegável que Wolf traz um outro aspecto da educação e levanta pontos essenciais para aqueles que fazem políticas públicas tanto no Reino Unido quanto em outras partes do no mundo. Porém, trazer essa discussão para o Brasil parece um luxo - como adverte a autora - quando grande parte da população sequer completa o segundo grau, e se o faz, muitas vezes não adquiriu o mínimo de qualificação necessária nem mesmo para conseguir um emprego, o que dirá para entrar em uma universidade pública... Talvez o livro possa servir como direcionador para aqueles que determinam os investimentos em educação no país e que se possa, ao invés de simplesmente copiar os modelos educacionais desenvolvidos no exterior, questionar sua validade no âmbito econômico nacional. 